\title{
Discontinuous gas exchange cycles and active ventilation in pupae of the bumblebee Bombus terrestris ${ }^{1}$
}

\author{
Marika MÄND $^{\mathrm{a} *}$, Aare KUUSIK ${ }^{\mathrm{a}}$, Ants-Johannes MARTIN ${ }^{\mathrm{a}}$, Ingrid H WILLIAMS ${ }^{\mathrm{b}}$, \\ Anne LUIK ${ }^{a}$, Reet KARISE ${ }^{\text {a }}$, Luule METSPALU ${ }^{a}$, Külli HIIESAAR ${ }^{a}$ \\ a Institute of Plant Protection, Estonian Agricultural University, Kreutzwaldi 64, 51014 Tartu, Estonia \\ ${ }^{b}$ Rothamsted Research, Harpenden, Hertfordshire, AL5 2JQ, UK
}

Received 2 October 2003 - revised 25 June 2004 - accepted 2 March 2005

Published online 19 October 2005

\begin{abstract}
Discontinuous release of $\mathrm{CO}_{2}$ (bursts) or discontinuous gas exchange cycles (DGC), metabolic rate (MR) and ventilation movements were simultaneously recorded from the pupae of the bumblebee Bombus terrestris by means of an electrolytic respirometer and an infrared gas analyser (IRGA) combined with an infrared actograph (IRA). After recovering from stress, the early stage pupae showed irregular continuous respiration, mid-stage pupae displayed regular DGC. The bursts of $\mathrm{CO}_{2}$ release tended to coincide with abdominal contractions. In late stage pupae all bursts of $\mathrm{CO}_{2}$ were associated with active ventilation. During interburst periods, spikes appeared on the respirograms interpreted as micro-cycles of passive suction ventilation (PSV). After removal from their cocoons, the pupae exhibited frequent periods of muscular activity due to stress. Water loss of pupae inside cocoons was significantly less than that from pupae without cocoons.
\end{abstract}

Bombus terrestris L. / passive suction ventilation / standard metabolic rate / respirometry

\section{INTRODUCTION}

Bumblebees, such as Bombus terrestris L. are known to be useful pollinators. The pollinating role of bees is vital to both agricultural and natural ecosystems, and in most temperate regions bumblebees are an important and sometimes indispensable component of the pollinator complex (Osborne and Williams, 1996). Their activity is dependent on their physiological state and health and it is therefore important to develop appropriate methods for assessing their physiological condition.

The physiological state and health of insects are usually estimated by measuring their standard metabolic rate (SMR). This is defined as a value measured at a particular temperature when an insect is quiet and inactive, is not digesting a meal and is not exposed to any stress (Withers, 1992). The pattern of gas exchange is another essential parameter indicating the physiological resting state of adult insects and pupae (Kestler, 1971). Many insects display a discontinuous gas exchange cycle (DGC), which means that $\mathrm{CO}_{2}$ is released in bursts and uptake of $\mathrm{O}_{2}$ often occurs cyclically (see reviews by Miller, 1981; Kestler, 1985; Slama, 1988; Lighton, 1994, 1996; Wasserthal, 1996). From spiracular activity, the gas exchange cycle can be described as having three phases: closed (C), flutter (F) and burst (B). C phase indicates that the spiracles are closed. $\mathrm{F}$ phase means that the spiracles open and closed rapidly and $0_{2}$ enters the tracheal systems by bulk

\footnotetext{
* Corresponding author: marika.mand@ut.ee
}

1 Manuscript editor: Jean-Noël Tasei 
flow or by diffusion or a combination of the two. During the B phase a sudden release, or burst, of carbon dioxide occurs. Moreover, cyclic $\mathrm{CO}_{2}$ release is a sensitive indicator of physiological stress in insects (Kestler, 1991).

Some studies have addressed gas exchange in adult bumblebees, mainly in hibernating queens (Silvola, 1984; Beekman and Stratum, 1999), or in workers at low temperatures (Kuusik et al., 2002). Adult bumblebees are almost continuously active and it is therefore difficult to measure their standard metabolic rate or their gas exchange patterns during normal activity at ambient temperature.

To date, information on gas exchange patterns and ventilation movements in bumblebee pupae within their cocoons have not been reported. It can be presumed that, when enclosed within the cocoon, the pupae are only weakly exposed to stress factors. To measure the gas exchange patterns and ventilation movements of pupae within cocoons, devices which allow the recording of gas exchange and abdominal contractions through the cocoon must be used.

This paper reports a study of the metabolic rate (MR), gas exchange patterns and ventilation movements in B. terrestris pupae inside their cocoons using combined non-invasive methods which allow simultaneous recording of these different activities at temperatures prevailing in the brood of bumblebee colonies.

\section{MATERIALS AND METHODS}

\subsection{Insects and weighing}

The colonies (Natupol hives) of the bumblebee B. terrestris were purchased from Koppert Biological Systems B.V. (the Netherlands). The colonies were kept in nest boxes in the laboratory at the temperature of $22-25^{\circ} \mathrm{C}$. All manipulations were carried out under red light. The temperature in the brood chambers was $28-30{ }^{\circ} \mathrm{C}$. All colonies were supplied with unlimited amounts of sugar or honey solution and fresh pollen collected from honey bee colonies. Neither colonies nor pupae used in this study were parasitised or infected by diseases.

For the experiments, pupae weighing at least $120 \mathrm{mg}$ were selected. The pupae used were of three age groups: (1) 25 early stage pupae with non-pigmented eyes and white body, (2) 35 mid-stage pupae with pigmented eyes and non-pigmented (white) body and (3) 30 late stage pupae with pigmented bodies.

After respirometry pupae with the cocoons removed were weighed to $0.1 \mathrm{~g}$ on an analytic balance. Body mass loss was measured gravimetrically, but then the pupae were weighed to $0.01 \mathrm{mg}$ using a microanalytic balance. During the measurements of mass loss, the pupae were kept at $22.0 \pm 0.5^{\circ} \mathrm{C}$ in ambient room humidity (55-65\% RH). The gravimetric method assumes that mass loss and water loss are equivalent in the pupal stage when there is no intake of food or water (see Hadley, 1994). Hence, assuming fat metabolism, pupal mass loss will be referred to below as water loss. All recordings were made at $28{ }^{\circ} \mathrm{C}$, which is the normal temperature for bumblebee brood (Heinrich, 1974).

\subsection{Constant-volume respirometry}

A differential electrolytic microrespirometeractograph was used for the sensitive recordings of gas exchange cycles and microcycles (Kuusik et al., 1992; Tartes and Kuusik, 1994; Tartes et al., 1999, 2000, 2002). This closed-system and constant volume micro-respirometer allowed simultaneous recording of metabolic rate, discrete $\mathrm{CO}_{2}$ releases (bursts), rapid intakes of air into the tracheae referred to as passive suction ventilation (PSV) in microcycles, and active abdominal movements. The rates of generation of oxygen by electrolysis are indicated on graphs as oxygen flux ' $\mathrm{F}_{02}\left(\mathrm{~mL} \mathrm{O}_{2} \mathrm{~h}^{-1}\right)$ '. They represent also the recorded transient $\mathrm{mL}$ rate changes of $\mathrm{CO}_{2}$ release or air intake as indicated.

The respirometer ensures continuous replacement of consumed oxygen with electrolytically produced oxygen. The insect itself plays an active role in this self-regulating system. Rapid changes of pressure in the insect chamber, caused by active body movements of the insect, or other rapid events, will lead to corresponding rapid changes in the electrolysis current reflected as spikes on recordings. Carbon dioxide release causes a rise of the liquid meniscus in the left side of the U-shape capillary (Fig. 1), thus, the photodiode is screened from the light beam. This event causes a temporary decrease in the electrolysis current and oxygen generation. In this way, $\mathrm{CO}_{2}$ bursts are not measured but only indicated on the respirogram as clear downward peaks lasting several minutes (Figs. 2, 3A), and these peaks we refer to as bursts of carbon dioxide. A $15 \%$ potassium hydroxide solution was used to absorb the $\mathrm{CO}_{2}$.

Most measurements were made using pupae enclosed within their cocoons, although some patterns were compared with those of enclosed pupae after their removal from cocoons $(\mathrm{N}=12)$. When the smallest volume changes in the insect chamber due to passive suction ventilation (PSV) were to be recorded using high resolution, then a small aperture 


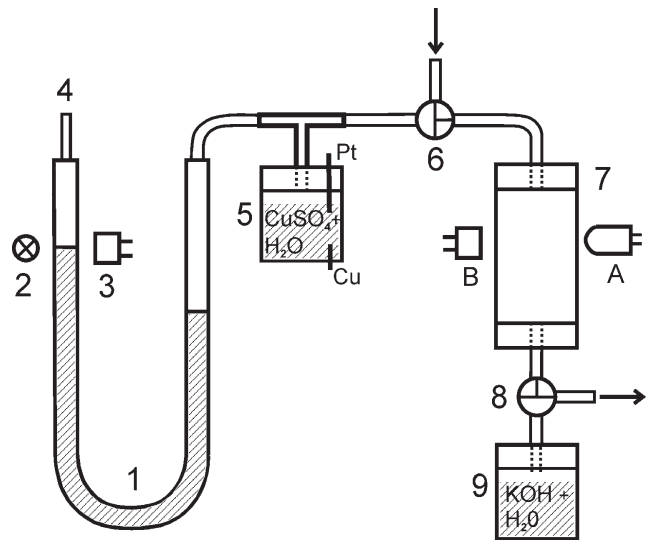

Figure 1. A scheme of the electrolytic respirometer, that may be switched to the flow-through system of an infrared gas analyser (IRGA). (1) Glass capillary with ethanol; (2) light source; (3) photodiode; (4) tubing to the compensation vessel (a thermos bottle $0.5 \mathrm{~L})$; (5) an electrolysis unit with $\mathrm{Cu}$ and Pt electrodes; (6) air inflow from the IRGA; (7) insect chamber with infrared-emitting diode (A) and infrared-sensor diode (B); (8) air outflow to the IRGA; (9) vessel for potassium hydroxide.

(about $1 \mathrm{~mm}^{2}$ ) was made in the cocoon near the head. The pupae without cocoons in the transparent insect chamber were sometimes visually observed for body movements using up to $40 \times$ magnification of a stereomicroscope (Olympus SZ 40).

\subsection{Flow-through respirometry}

The infrared gas analyser, or IRGA (Infralyt-4, VEB, Junkalor, Dessau), was used to prove that the presumed $\mathrm{CO}_{2}$ signals; i.e., the downward peaks on the recording of the electrolytic respirometer, were actually due to $\mathrm{CO}_{2}$ bursts and to measure them quantitatively (Fig. 3B). IRGA was calibrated at the different flow rates by means of calibration gases (Trägergase, VEB, Junkalor, Dessau) and with gas injection. Air flow rates from 3.6 to $10.8 \mathrm{~L}$ per $\mathrm{h}$ were used; the lower air flow rates gave higher sensitivity. The insect chamber could be switched either to the IRGA or to the electrolytic respirometer without disturbing the insect as seen in Figure 1 (see also Martin et al., 2004).

\subsection{Infrared actography}

The electrolytic respirometer and IRGA both were combined with an infrared (IR) cardiograph, which we refer to as the IR actograph (IRA), because it records not only heart pulses but also all other abdominal contractions. An IR-emitting diode was placed on one side of the chamber near the ventral side of the abdomen, while an IR-sensitive diode was placed on the opposite side of the chamber. The light from the IR-diode was modulated by the contractions of the heart and skeletal muscles. The level of output voltage reflected the vigour of the muscular contractions of the insect (see Hetz, 1994; Hetz et al., 1999; Metspalu et al., 2001, 2002; Kuusik et al., 2002). Abdominal contractions resulted in downward spikes, muscular relaxations were directed upward.

\subsection{Data acquisition and statistics}

Computerized data acquisition and analysis were performed using DAS 1401 A/D hardware (Keithley, Metrabyte, USA) with a $10 \mathrm{~Hz}$ sampling rate. The mean metabolic rate was automatically calculated by averaging data over a period involving at least 3 periods of activity or at least 12 cycles of gas exchange; i.e., a period lasting at least 1 hour.

Means, standard deviations and the number of observations $(\mathrm{N})$ are reported. Tests were performed using a statistic package StatSoft ver. 6, Inc./USA. Means were compared using Student's t-test or by repeated measures ANOVA, after testing for homogeneity of variances. The level of significance for all tests was $P \leq 0.05$.

\section{RESULTS}

\subsection{Cyclic release of carbon dioxide and active ventilation}

During the first 2-3 hours of recording, the pupae enclosed within a cocoon, displayed activity periods recorded as irregular spikes on both on the respirograms and on the recordings of infrared actograph (Fig. 2A). The irregular pattern comprised several events: abdominal contractions, heartbeats and small bursts of $\mathrm{CO}_{2}$. These were quite similar to those previously recorded from pupae after removal from their cocoons. However, the resting periods of pupae within cocoons became gradually longer lasting 20-50 min alternating with activity (Fig. 2A). During the resting period, clear small fluttering bursts of $\mathrm{CO}_{2}$ release in microcycles were recorded from mid-pupae with a frequency of 9-14 bursts per hour (mean $12.6 \pm$ 2.5 bursts $\mathrm{h}^{-1}$ ), with each burst lasting 1-2 minutes (Fig. 2A). In young pupae we did not detect the clear cycles of gas exchange. 

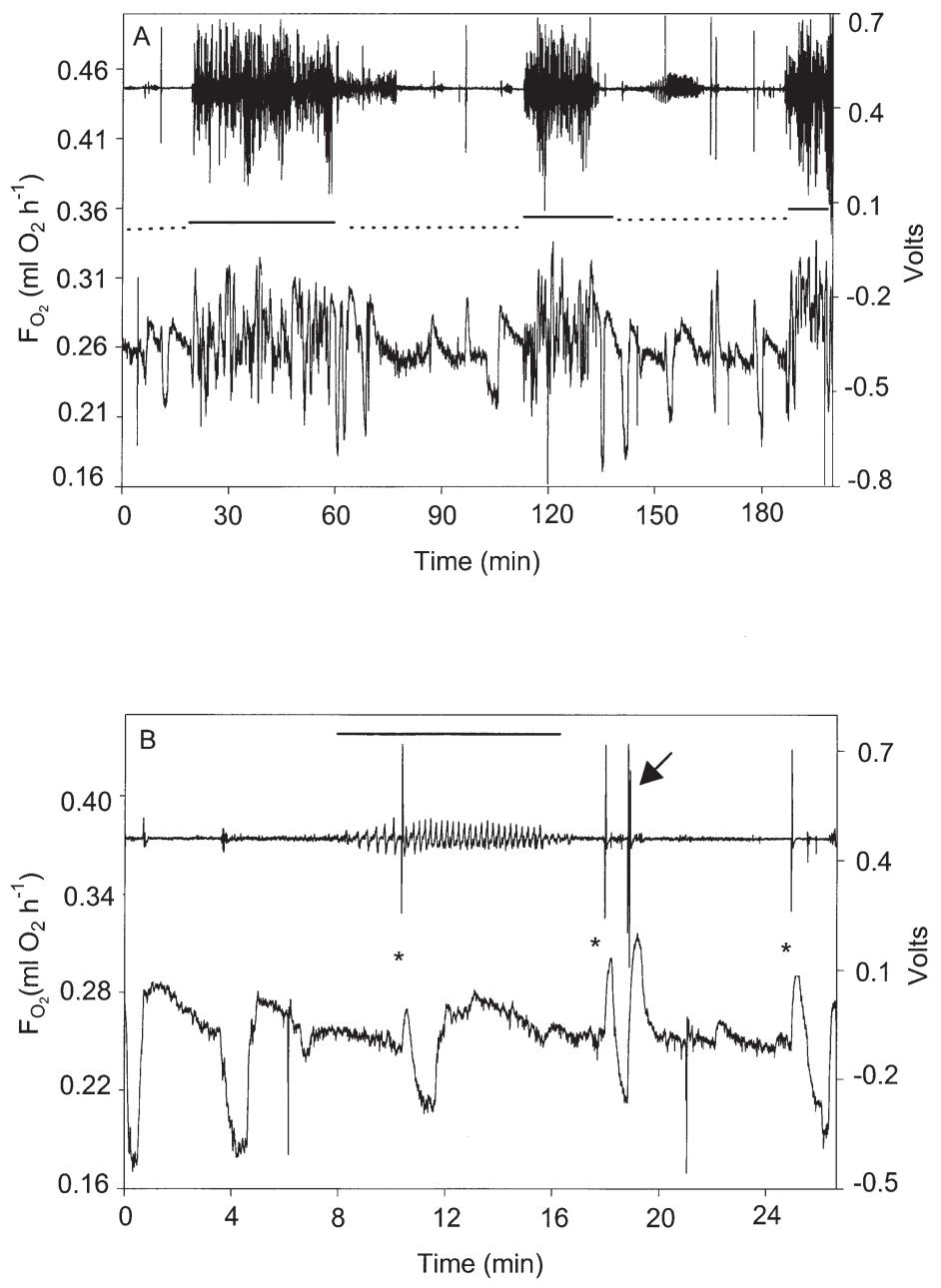

Figure 2. (A) A typical pattern of muscular activity (solid line) alternating with the resting periods (dotted line) in a mid-stage pupa of Bombus terrestris $(525 \mathrm{mg})$ enclosed within a cocoon. The lower trace (left axis) is a recording of the electrolytic respirometer; the upper trace (right axis) is a simultaneous recording of infrared actograph. (B) A detail of the right part of the upper figure: a resting period with bursts of $\mathrm{CO}_{2} ;$ note that most of the bursts begin with an upward spike (indicated by asterisks) due to an inspiration stroke (lower trace, a recording of electrolytic respirometer). The upper trace is the simultaneous recording of infrared actograph; note that each inspiration stroke is associated with an abdominal movement. A short ventilation bout is denoted by arrow. The horizontal line is a period of heartbeat. (C) A detail of the upper figure made with higher time resolution. 
After 3-4 hours of recording, the irregular bouts of vigorous abdominal contractions ceased and clear and regular bursts of $\mathrm{CO}_{2}$ appeared with the frequency of 4-10 (mean $7.3 \pm 1.9$ ) per h (Fig. 2B). In addition, the cyclic gas exchange was not interrupted by irregular bouts of vigorous abdominal contractions.

After removal from the cocoon, the pupae showed long periods of abdominal contractions or activity, alternating with short resting periods. The latter usually lasted less than 5 minutes, and were thus too short to monitor gas exchange rhythms and other events. The patterns of activity were quite similar to those recorded in pupae inside cocoons (Fig. 2A). However, there occurred also mid-stage pupae and late stage pupae displaying clear cyclic gas exchange soon after removal from their cocoons.

Many (about $60 \%$ ) of the small bursts began with an inspiration movement of the abdomen and oxygen uptake. This was reflected on the recording trace as an upward peak and simultaneously on the recording of infrared actograph as a spike due to a muscular contractionrelaxation or abdominal compression-decompression. Sometimes a short bout of $2-4$ strokes of ventilation movements occurred during the final part of the burst of carbon dioxide (Fig. 2C).

In mid-stage pupae the abdominal contractions during the ventilation periods tended to coincide with the bursts of carbon dioxide, with many of the contractions occurring in groups (bouts) at the same time as the bursts of carbon dioxide (Fig. 3A, B). However, during some interburst periods, single movements occurred. About $20 \%$ of the mid-stage pupae displayed clear DGC, where the bursts of $\mathrm{CO}_{2}$ were accompanied by abdominal ventilating movements. In late stage pupae, all abdominal contractions, interpreted as active ventilation, were strongly associated with the bursts of carbon dioxide (Fig. 4).

\subsection{Passive suction ventilation (PSV)}

PSV occurred between the $\mathrm{CO}_{2}$ bursts in flutter periods when air was sucked periodically into the tracheae when the spiracles were slightly opened for a fraction of a second (0.2$0.3 \mathrm{~s})$ and then when they closed, after which a slight negative intra-tracheal pressure devel- oped. This type of gas exchange formed a typical pattern on the respirogram: an almost vertical upward spike due to the microopening of the spiracles, followed by a descending trace after the closure of the spiracles (Fig. 5) during micro-constrictions where even the minute flutters (nano-cycles) could be resolved. Visual observations through the microscope during recording showed telescoping movements of the abdominal segments: rapid retraction followed by slow passive contraction due to internal $\mathrm{O}_{2}$ consumption and tracheal and abdominal collapse.

This typical pattern of PSV was most clearly recorded in mid-stage pupae when the interburst periods lasted 5-8 minutes. The PSV was not detected in the early stage pupae, probably because their soft integument does not allow development of negative intratracheal pressure. The frequency of PSV ranged from 80 to 115 (mean $96 \pm 12$ ) per hour. The corresponding $\mathrm{CO}_{2}$ release is shown in Figures 3 and 4 as the typical flutter period pattern.

\subsection{Metabolic rate and water loss}

Late stage pupae enclosed in cocoons exhibited significant differences in metabolic rate between activity and resting periods $\left(1.29 \pm 0.27 \mathrm{~mL} \mathrm{O}_{2} \mathrm{~g}^{-1} \mathrm{~h}^{-1}\right.$ and $1.07 \pm$ $0.28 \mathrm{~mL} \mathrm{O}_{2} \mathrm{~g}^{-1} \mathrm{~h}^{-1}$, respectively; Student's ttest, $\mathrm{t}=2.54$, df $=38, P<0.05 ; \mathrm{N}=4$ pupae each with 5 activity and 5 resting periods). Thus metabolic rate during intermittent activity was about $20 \%$ higher than during resting. After 4-5 hours of recording when no activity periods occurred, the standard metabolic rate for enclosed mid-stage pupae and late stage pupae was determined to be $0.35 \pm 0.08 \mathrm{~mL} \mathrm{O}_{2} \mathrm{~g}^{-1} \mathrm{~h}^{-1}$ and $0.82 \pm$ $0.12 \mathrm{~mL} \mathrm{O}_{2} \mathrm{~g}^{-1} \mathrm{~h}^{-1}$, respectively.

The metabolic rate during continuous activity of pupae removed from cocoons did not differ from that of enclosed pupae during their activity periods $\left(1.52 \pm 0.46 \mathrm{~mL} \mathrm{O}_{2} \mathrm{~g}^{-1} \mathrm{~h}^{-1}\right.$ and $1.29 \pm 0.27 \mathrm{~mL} \mathrm{O}_{2} \mathrm{~g}^{-1} \mathrm{~h}^{-1}$, respectively, $\mathrm{N}=20$ pupae of both group; Student's t-test, $\mathrm{t}=1.8$, $\mathrm{df}=38, P=0.07$ ).

Water loss in late stage pupae within cocoons differed significantly from that of late stage pupae removed from their cocoons $(0.21 \pm$ $0.04 \mathrm{mg} \mathrm{g}^{-1}$ day $^{-1}$ and $0.34 \pm 0.05 \mathrm{mg} \mathrm{g}^{-1}$ day $^{-1}$, respectively, $\mathrm{N}=10$ pupae; repeated measures 

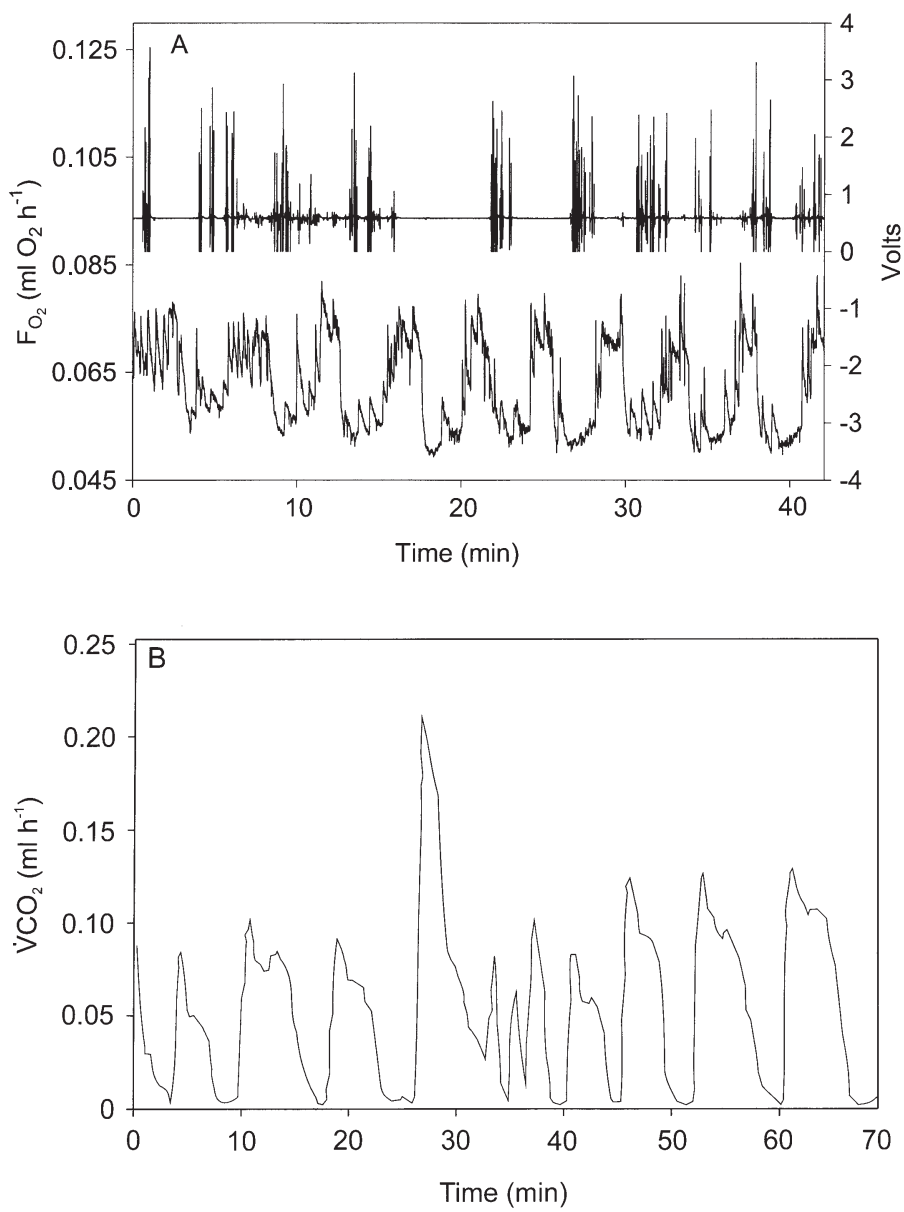

Figure 3. (A) A simultaneous recording of infrared actograph (upper trace, Volts) and electrolytic respirometer (lower trace) showing a coinciding trend of the abdominal contractions with the bursts of $\mathrm{CO}_{2}$ release in mid-stage pupa of $B$. terrestris $(181 \mathrm{mg})$. Between 18-20 min a burst of carbon dioxide occurs, which is not associated with active ventilation, the other bursts are accompanied with abdominal ventilating movements. (B) The bursts of $\mathrm{CO}_{2}$ release recorded in the same pupae after switching the electrolytic respirometer to the infrared gas analyser. An activity period is seen between 30 and $40 \mathrm{~min}$ of the recording.

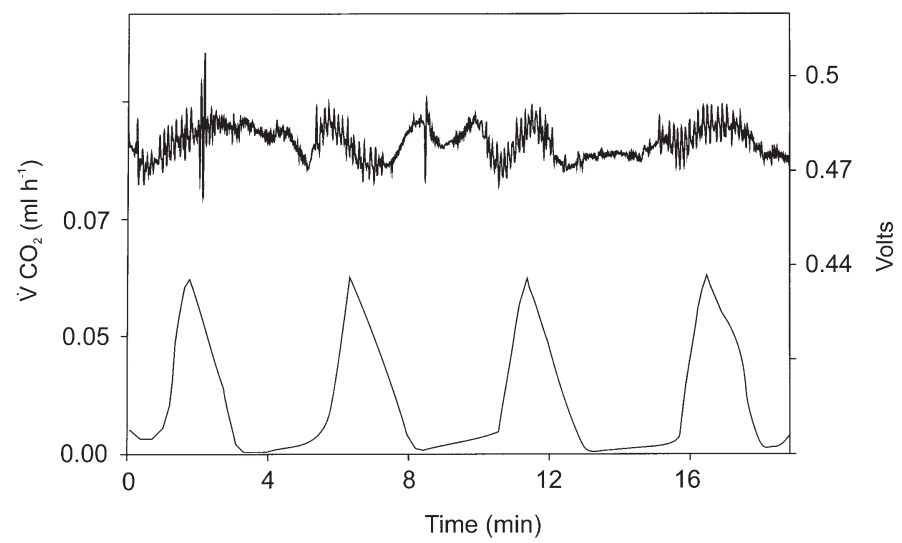

Figure 4. A simultaneous recording of infrared actograph (upper trace, Volts) and infrared gas analyser (lower trace) representing the regular bursts of carbon dioxide in a late stage pupa of B. terrestris $(280 \mathrm{mg})$. Note that the clear pattern of active ventilation (upper trace) coincided with bursts of $\mathrm{CO}_{2}$ (lower trace). 


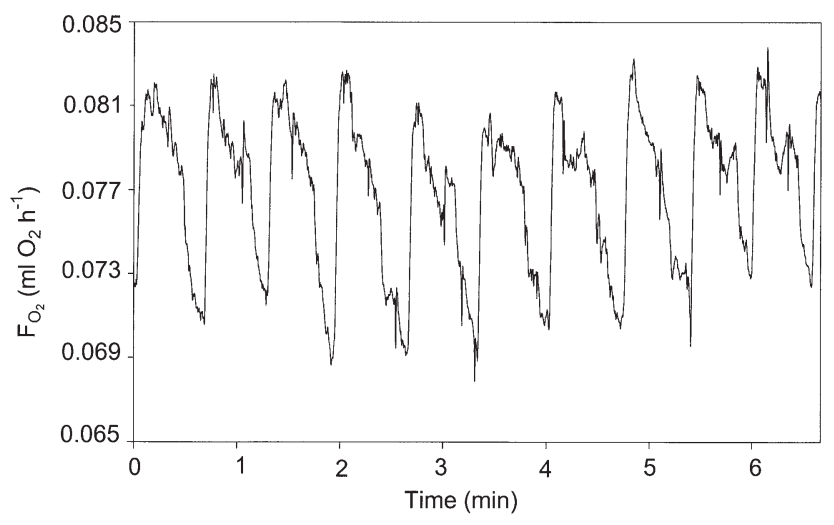

Figure 5. A typical pattern of passive suction ventilation in microcycles during an interburst period in a mid-stage pupa of $B$. terrestris $(280 \mathrm{mg})$ recorded with an electrolytic respirometer. The almost vertical lines are due to the opening of the spiracles and convective and diffusive uptake of oxygen into the tracheae. The declining part of trace indicates the closing of the spiracles interrupted by nano-openings (flutter).

ANOVA, $\left.\mathrm{F}_{1,9}=91.0, P<0.01\right)$. Water loss of pupae after their removal from the cocoons rose noticeably due to the almost continuous activity. However, the cocoon itself could retard the transpiratory water loss from the pupa suggesting a vapour gradient between the saturated stagnant layer around the pupa and the ambient air which runs through the cocoon.

\section{DISCUSSION}

In the present study, we used methods, which allowed simultaneous recording of metabolic rate and the normal patterns of the gas exchange and ventilatory movements of pupae of the bumblebee $B$. terrestris that had not been removed from their cocoons, which minimized stress to the insect.

It is well known that several stress factors may abolish the normal gas exchange cycles or cause their irregularity (Kestler, 1991; Möbius et al., 1996). Most of the B. terrestris pupae removed from their cocoons displayed an irregular pattern of gas exchange and body movements due to the abnormal environment, handling and apparatus stress. These activity periods sometimes alternated with resting periods, which were too short to observe normal patterns of gas exchange and body obligatory movements.
In this study, clear gas exchange cycles were recorded both in mid-stage and in late stage bumble bee pupae. Enclosed in the cocoon, the activity periods gradually shortened alternating with inactivity when short relatively frequent gas exchange cycles were displayed (914 per h) in mid-pupae and late pupae. Further the activity periods were lost and regular larger bursts of $\mathrm{CO}_{2}$ appeared (4-10 per h).

Previous studies have shown that adult foragers of $B$. terrestris exhibit DGC where all bursts of $\mathrm{CO}_{2}$ are accompanied by active ventilating movements with a frequency of about two cycles per hour, when measured at $5{ }^{\circ} \mathrm{C}$ (Kuusik et al., 2002), and that pre-diapause queens of $B$. terrestris exhibit two large DGC per hour at $18{ }^{\circ} \mathrm{C}$ (Beekman and Stratum, 1999).

In mid-stage pupae, weak abdominal contractions tended to coincide with the bursts; i.e., FV cycles were observed (Fig. 3A), however there occurred also FO cycles, where no ventilating movements were recorded. In late stage pupae (Fig. 4), only FV cycles were recorded, where all bursts of $\mathrm{CO}_{2}$ were accompanied by movements of active ventilation with the frequency of 50-60 movements per hour.

Insect pupae exhibit a great diversity in their patterns of obligatory abdominal movements and in the coordination of these movements with gas exchange cycles (Tartes et al., 2002). Regular bouts of weak abdominal movements 
have been described in pupae of the great wax moth Galleria mellonella (Kuusik et al., 1996; Tartes et al., 1999) but in this species bouts occurred independently of the short gas exchange cycles. Pupae of the Colorado potato beetle Leptinotarsa decemlineata exhibited large, small and microbursts of $\mathrm{CO}_{2}$ but only the large bursts were associated with active ventilation bouts (Tartes et al., 2000; Kuusik et al., 2001).

In the mid-stage pupae of $B$. terrestris, we observed that not only $\mathrm{CO}_{2}$ release but also $\mathrm{O}_{2}$ uptake was intermittent. Each small burst in mid-stage pupa began with an inflow of $\mathrm{O}_{2}$ into the tracheae. Similar patterns of intermittent $\mathrm{O}_{2}$ uptake have also been recorded from the pupae of G. mellonella (Kuusik et al., 1996) and of Pieris brassicae (Harak et al., 1999) using the same type of electrolytic respirometers. Intermittent $\mathrm{O}_{2}$ uptake has also been reported from adults of the ant Formica polyctena (Martin et al., 2004) and several other insect species, mostly Coleoptera (Punt et al., 1957; Lighton, 1988; Bartholomew et al., 1985).

We recorded clear and real cycles of gas exchange in late stage pupae and even in pupae during mid-stage pupal development. We observed a typical pattern of PSV in microcycles of micro-constrictions, and micro-openings during the interburst periods of mid-stage pupae of B. terrestris are also probably typical. A similar pattern of PSV has been recorded from adult ants (foragers) of the species $F$. polyctena (Kuusik et al., 2004). The PSV acts as water conserving mechanism in many insects (see Kestler, 1978, 1980, 1982, 1985). In contrast to flow-through respirometry we can measure for the first time the combined $\mathrm{O}_{2}$ uptake by convection and by simultaneous diffusion as described in the theory of diffusive convective gas exchange by Kestler (1985). Figure 3 shows that not more than $21 \%$ of the volume of tracheal collapse in the micro-constriction period can be replaced by convection as the inflowing air contains only $21 \%$ oxygen. The rest or even more must be diffusion, which is modified by convection.

Herford (1938) observed PSV as the pulsations of tracheal collapse first in the soft skinned transparent flea. The tracheal collapse is caused by the faster decrease of the tracheal oxygen pressure $\left(\mathrm{P}_{\mathrm{O}_{3}}\right)$ than the rise in the pressure of carbon dioxide $\left(\mathrm{P}_{\mathrm{CO}_{2}}\right)$, which causes a pressure fall. It leads to an abdominal collapse as the compliant system shows higher volume than pressure change also observed in hard skinned Hyalophora cecropia and Attacus atlantis pupae. The lack of micro-cycles and PSV at higher SMR in discontinuous gas exchange cycle of early and late stage pupae is probably due to the fact that the spiracles start the micro-opening from a minimal basal opening width, which means that rapid air suction inflow into the tracheae can not occur (Kestler, 1985).

In our study, the simultaneous IRA recordings and respirograms allowed easy discrimination of the periods of activity and inactivity. From our results we also concluded that the respiration pattern and the obligatory abdominal movements in the pupal stage of bumblebees should be studied without removing the pupa from the cocoon to avoid the stress induced by handling, apparatus and environment.

\section{ACKNOWLEDGEMENTS}

We thank Paul Kestler for his helpful review of an earlier version of the manuscript, and we thank three anonymous referees for their constructive comments. This work was supported by Grants from the Estonian Science Foundation, No. 5737, No. 5330 and, No. 4993. Rothamsted Research is grant-aided by the Biotechnology and Biological Sciences Research Council, UK.

Résumé - Cycles d'échanges gazeux et ventilation active chez les nymphes du bourdon Bombus terrestris. Les bourdons sont connus pour être d'utiles pollinisateurs. Leur activité dépend de leur état physiologique et de leur santé et il est donc important de mettre au point des méthodes appropriées pour évaluer leurs conditions physiologiques. On ne dispose pas à l'heure actuelle de données sur les schémas d'échanges gazeux, ni sur les mouvements de ventilation chez les nymphes de bourdons à l'intérieur de leur cocon. Cet article rend compte d'une étude portant sur le taux métabolique (MR), les schémas d'échanges gazeux et les mouvements de ventilation chez les nymphes de Bombus terrestris L. à l'intérieur de leur cocon.

Nous avons enregistré simultanément le taux métabolique basal (SMR), l'émission discontinue de bouffées et de micro-bouffées de $\mathrm{CO}_{2}$ et la consommation cyclique d'oxygène, i.e. les cycles discontinus d'échanges gazeux (DGC), ainsi que les mouvements de ventilation sur des nymphes d'âge moyen et des nymphes âgées de $B$. terrestris, sans les extraire de leur cocon. Un actographe-microrespiromètre électrolytique a été utilisé pour enregistrer 
les DGC et les SMR. Le respiromètre était couplé à un actographe infrarouge (IRA). La chambre de l'insecte pouvait être reliée soit à l'analyseur de gaz infrarouge (IRGA), soit au respiromètre électrolytique sans perturbation pour l'insecte (Fig. 1).

Cette étude a permis d'enregistrer pour la première fois des cycles d'échanges gazeux nets chez les nymphes d'âge moyen et chez les âgées. Chez ces dernières toutes les bouffées de $\mathrm{CO}_{2}$ étaient associées à une ventilation active (Fig. 4). Chez les nymphes plus jeunes, seul un échange gazeux plus continu a été observé, vraisemblablement en raison du tégument trop mou du corps. La ventilation passive par succion (PSV) s'est produite chez les nymphes quand l'air était aspiré périodiquement dans les trachées lors de micro-ouvertures des spiracles puis de leur fermeture. Ce type d'échange gazeux a donné un profil typique sur le respirogramme (Fig. 5). Après avoir été extraites de leur cocon, les nymphes ont perdu significativement plus d'eau en raison de leur activité presque continue.

Nous en concluons que le profil respiratoire au stade nymphal doit être étudié sans que la nymphe ne soit extraite du cocon, afin d'éviter le stress induit par la manipulation, l'appareil et l'environnement.

Bombus terrestris / échanges gazeux discontinus / ventilation passive par succion / taux métabolique de base / respirométrie

\footnotetext{
Zusammenfassung - Diskontinuierliche Gasaustauschzyklen und aktive Ventilierung bei Puppen der Hummel Bombus terrestris. Hummeln sind wichtige Bestäuber und ihre Aktivität hängt von ihrem physiologischen und Gesundheitszustand ab. Aus diesem Grund ist es wichtig, angemessene Methoden zur Bestimmung des physiologischen Zustands zur Hand zu haben. Für die Puppenphase gibt es für Hummeln bisher keine Informationen zum Gasaustausch und zur Ventilation. Die vorliegende Arbeit erhebt erstmals solche Informationen zur Metabolismusrate (MR), zum Gasaustauschmuster und zu Ventilationsbewegungen bei Bombus terrestris L. Puppen, die in ihren Kokons belassen wurden.

Die Standardmetabolismusrate (SMR), die diskontinuierliche $\mathrm{CO}_{2}$-Abgabe in Form von Stössen oder Mikrostössen und die zyklische Aufnahme von Sauerstoff, d.h. die diskontinuierlichen Gasaustauschzyklen(DGC) wurden simultan mit den Ventilationsbewegungen an mittleren bis späten Puppenstadien registriert. Die Puppen verblieben hierzu innerhalb ihres jeweiligen Kokons. Für die DGC und SMRRegistrierung wurde ein elektrolytischer Mikrospirometer-Aktograph eingesetzt. Das Respirometer war mit einem Infrarot-Aktograph (IRA) kombiniert, und die Insektenkammer konnte zwischen dem Infrarot-Gasanalysator (IRGA) und dem elektrolytischen Respirometer hin- und hergeschaltet werden, ohne das Insekt zu stören (Abb. 1). Im späten Puppenstadium waren alle $\mathrm{CO}_{2}$-Abgabestösse mit akti-
}

ven Ventilationsbewegungen verbunden (Abb. 4), während in früheren Puppenstadien, offensichtlich bedingt durch das noch zu weiche Integument, ein kontinuierlicherer Gasaustausch zu beobachten war. Eine passive Suktionsventilierung (PSV) war zu beobachten, wenn Puppen periodisch Luft in die Tracheen einsogen. Die Stigmata wurden dazu kurzzeitig geöffnet und dann wieder geschlossen. Diese Art des Gasaustausches bildete das typische Muster in den Respirogrammen (Abb. 5). Nach der Entnahme aus ihren Kokons stieg bei Puppen der Wasserverlust signifikant an, offensichtlich als Konsequenz ihrer kontinuierlichen Aktivität. Der Kokon scheint also den respiratorischen Wasserverlust bei Puppen in Grenzen zu halten. Zur Vermeidung von Stress als Folge von Manipulation, Apparatur und Umgebungsbedingungen sollten deshalb bei Hummeln Untersuchungen zur Atmungsphysiologie im Puppenstadium stets innerhalb der Kokons durchgeführt werden.

Bombus terrestris / passive Suktionsventilation / Standardmetabolismusrate / Respirometrie

\section{REFERENCES}

Bartholomew G.A., Lighton J.R.B., Louw G.N. (1985) Energetics of locomotion and patterns of respiration in tenebrionid beetles from the Namib desert, J. Comp. Physiol. B 155, 155-162.

Beekman M., Stratum van P. (1999) Respiration in bumblebee queens: effect of life phase on the discontinuous ventilation cycle, Entomol. Exp. Appl. 92, 295-298.

Hadley N.R. (1994) Ventilatory patterns and respiratory transpiration in adult terrestrial insects, Physiol. Zool. 67, 175-189.

Harak M., Lamprecht I., Kuusik A., Hiiesaar K., Metspalu L., Tartes U. (1999) Calorimetric investigations of insect metabolism and development under the influence of a toxic plant extract, Thermochim. Acta 333, 39-48.

Heinrich B. (1974) Der Hummelstaat, List Verlag, München, Leipzig.

Herford G.M. (1938) Tracheal pulsation in the flea, J. Exp. Biol. 15, 327-338.

Hetz S.K. (1994) Untersuchung zu Atmung, Kreislauf und Säure-Basen-Regulation an Puppen der tropischen Schmetterlingsgattungen Ornithoptera, Troides and Attacus, Dissertation zur Erlangung des Doktorgrades, University Erlangen-Nürnberg.

Hetz S.K., Psota E., Wasserthal L.T. (1999) Roles of aorta, ostia and tracheae in heartbeat and respiratory gas exchange in pupae of Troides rhadamantus Staudinger 1888 and Ornithoptera priamus L. (Lepidoptera, Papilionidae), Int. J. Insect Morphol. Embryol. 28, 131-144. 
Kestler P. (1971) Die discontinuierliche Ventilation bei Perplaneta americana L. und anderen Insekten, Published Thesis Julius-Maximilians-University, Würzburg.

Kestler P. (1978) Atembewegungen und Gasaustausch bei Ruheatmung adulter terrestrischer Insekten, Verh. Dtsch. Zool. Ges. 1978, 269.

Kestler P. (1980) Saugventilation verhindert bei Insekten die Wasserabgabe aus dem Tracheensystem, Verh. Dtsch. Zool. Ges. 1980, 306.

Kestler P. (1982) Wie verhindern Stigmen den Wasserverlust, Verh. Dtsch. Zool. Ges. 1982, 262.

Kestler P. (1985) Respiration and respiratory water loss, in: Hoffmann K.H. (Ed.), Environmental Physiology and Biochemistry of Insects, SpringerVerlag, Berlin, pp. 137-183.

Kestler P. (1991) Cyclic $\mathrm{CO}_{2}$ release as a physiological stress indicator in insects, Comp. Biochem. Physiol. 100 C, 207-211.

Kuusik A., Metspalu L., Hiiesaar K., Tartes U. (1992) Further investigation on the respiration in pupae Galleria mellonella: records of body length changes, spiracular rhythms and $\mathrm{CO}_{2}$ release, Proc. Eston. Acad. Sci. 41, 14-24.

Kuusik A., Harak M., Hiiesaar K., Metspalu L., Tartes U. (1996) Different types of external gas exchange found in pupae of greater wax moth Galleria mellonella, Eur. J. Entomol. 93, 23-35.

Kuusik A., Tartes U., Vanatoa A., Metspalu L., Hiiesaar K. (2001) Body movements and their role as triggers of heart activity in pupae of Colorado potato beetle Leptinotarsa decemlineata, Physiol. Entomol. 26, 158-164.

Kuusik A., Martin A.-J., Mänd M., Hiiesaar K., Metspalu L., Tartes U. (2002) Interrelations of gas exchange cycles, body movements and heartbeats in the foragers of bumblebee Bombus terrestris (Hymenoptera: Apidae) at low temperatures, Eur. J. Entomol. 99, 209-214.

Kuusik A., Martin A.-J., Mänd M., Metspalu L., Tartes U., Lind A. (2004) Cyclic release of carbon dioxide accompanied by abdominal telescoping movements in forager ants of Formica polyctena (Hymenoptera, Formicidae), Physiol. Entomol. 29, 152-159.

Lighton J.R.B. (1988) Simultaneous measurement in oxygen uptake and carbon dioxide emission during discontinuous ventilation in the tok-tok beetle, Psammodes striatus, J. Insect Physiol. 34, 361367.

Lighton J.R.B. (1994) Discontinuous ventilation in terrestrial insects, Physiol. Zool. 67, 142-162.

Lighton J.R.B. (1996) Discontinuous gas exchange in insects, Annu. Rev. Entomol. 41, 309-324.
Martin A.-J., Kuusik A., Mänd M., Metspalu L., Tartes U. (2004) Respiratory patterns in nurses of the red wood ant Formica polyctena (Hymenoptera, Formicidae), Insectes Soc. 51, 62-66.

Metspalu L., Kuusik A., Hiiesaar K., Jõudu J., Tartes U., Harak M. (2001) Simultaneous recording of gas exchange cyclicity, body movements and heartbeats by infrared-optical method in pupae of Leptinotarsa decemlineata (Say), Norw. J. Entomol. 48, 91-96.

Metspalu L., Kuusik A., Hiiesaar K., Tartes U. (2002) Tonic immobility in adult Colorado potato beetle, Leptinotarsa decemlineata (Coleoptera: Chrysomelidae) evoked by mechanical and optical stimuli, Eur. J. Entomol. 99, 215-219.

Miller P.L. (1981) Ventilation in active and inactive insects, in: Herreid C.F., Fourtner C.R. (Eds.), Locomotion and energetics in Arthropods, Plenum Press, New York, pp. 367-390.

Möbius P., Kestler P., Penzlin H. (1996) Studies on the function of octopamin in stress response of Periplaneta americana L., Verh. Dtsch. Zool. Ges. 89, 69.

Osborne J.L., Williams I.H. (1996) Bumble bees as pollinators of crops and wild flowers, in: Matheson A. (Ed.), Bumble bees for pleasure and profit, International Bee Research Association, Cardiff, UK, pp. 24-32.

Punt A., Parser W.J., Kuchlein J. (1957) Oxygen uptake in insects with cyclic $\mathrm{CO}_{2}$ release, Biol. Bull. 112 , 108-119.

Silvola J. (1984) Respiration and energetic of the bumblebee Bombus terrestris queen, Holarctic Ecol. 7, 177-181.

Slama K. (1988) A new look at insect respiration, Biol. Bull. Mar. Biol. Lab., Woods Hole 175, 289-300.

Tartes U., Kuusik A. (1994) Periodic muscular activity and its possible functions in pupae of Tenebrio molitor, Physiol. Entomol. 19, 216-222.

Tartes U., Kuusik A., Vanatoa A. (1999) Diversity in gas exchange and muscular activity patterns in insect studied by respirometer-actograph, Physiol. Entomol. 24, 150-157.

Tartes U., Kuusik A., Hiiesaar K., Metspalu L., Vanatoa A. (2000) Abdominal movements, heartbeats and gas exchange in pupae of the Colorado potato beetle, Leptinotarsa decemlineata, Physiol. Entomol. $25,151-158$.

Tartes U., Vanatoa A., Kuusik A. (2002) The insect abdomen - a heartbeat manager in insects, Comp. Biochem. Physiol. 133, 187-199.

Wasserthal L.T. (1996) Interaction of circulation and tracheal ventilation in holometabolous insects, Adv. Insect Physiol. 26, 297-351.

Withers P.C. (1992) Comparative Animal Physiology, Saunders College, Fort Worth. 